\title{
Klebsiella-induced purpura fulminans in a Nigerian child: Case report and a review of Literature
}

\author{
W. A. Olowu \\ Paediatric Nephrology Unit, Department of Paediatrics \\ Obafemi Awolowo University Teaching Hospitals complex \\ PMB 5538, Ile-Ife, Osun State, Nigeria.
}

\section{Summary}

Purpura fulminans (PPF) is a very severe but rare acute thrombohaemorrhagic illness of infants and young children. It occurs mainly, in patients with either congenital or acquired deficiencies of proteins $C$ and $S$ and antithrombin III.

Features of PPF include disseminated intravascular coagulopathy, symmetrical necrotic purpura and/or ecchymoses and symmetrical peripheral gangrene; digital and/ or limb(s) amputations and end-organ failure(s) may also occur.

The case of a 3.5 year-old Nigerian girl, who developed PPF following Klebsiella-rhinoscleromatis septicaemia is reported to illustrate the seriousness of the disease and the need for early diagnosis and management.

Keywords: Septiceamia, Purpura fulminans, Renal failure, Skin necrosis, Digital gangrene, Autoamputations.

\section{Résumé}

Le Purpura fulminans (PPF) est une maladie thrombohémorrhaique très grave mais rare chez les bébés et les petits enfants. Elle se produit en grande partie chez les patients soit avec congénital ou déficiences des protéines $\mathrm{C}$ et $\mathrm{S}$ acquis et anti-thrombin III.

Les traits de caractère de PPF comportent: la coagulopathie disséminée intravasculaire, purpura nécrotique symétrique et/ou l'ecchymoses et la gangrène symétrique périphérique digital et/ou amputation des membres et échec du fonctionnement de bout des organes pourrait arriver.

Il s'agit d'une analyse d'un cas d'une fille nigeriane âgée de 3, 5 ans qui avait contracté le PPF par suite de la septicaemie klebsiellarhinoscleromatis afin de démontrer la gravité de la maladie et le besoin de fairer la diagnose et le traitement à la première occasion ou dans le plus bref délai possible.

\section{Introduction}

Purpura fulminans (PPF) is a very severe but rare acute illness of infants and young children ${ }^{1-4}$; few cases, however, had been reported in adults $\mathrm{s}^{3,5}$. Like disseminated intravascular coagulation (DIC), haemolytic uraemic syndrome (HUS), and thrombotic thrombocytopaenic purpura (TTP), PPF is a consumptive thrombohaemorrhagic disorder (CTHD) $)^{1,6}$. PPF is characterised by DIC features, uniformly symmetrical necrotic purpura and/or ecchymoses, symmetrical peripheral gangrene and amputations ${ }^{2,3.5}$; furthermore, renal cortical necrosis (resulting in renal failure), ischaemic encephalopathy, ocular lesions, gastrointestinal ulceration, and adrenal gland necrosis secondary to severe, widespread microcirculation thromboses may form part of the clinical picture in some cases ${ }^{1,3,5}$. Although PPF can be provoked by any infection, acute varicella, streptococcal and meningococcal infections appear to be commonly implicated $\mathrm{d}^{2,3,5,7}$.

This condition possibly represents a very severe form of DIC because unlike HUS and TTP, there is associated consumption of coagulation factors ${ }^{1-4,7}$, leading to prolonged prothrombin time (PT) and partial thromboplastin time (PTT); thrombocytopaenia is, however, common to all the CTHDs ${ }^{1,6}$. DIC features associated with PPF, are initiated by vascular injury caused by the infecting organism. Bacterial endotoxins for example, mediate vascular injury through a variety of effects on the alternate pathway of complement, neutrophils, endothelial cells, factor XII and monocytes ${ }^{8,9}$. Activated monocytes secrete proinflammatory cytokines namely: tumour necrosis factor alpha ( $\mathrm{INF}-\alpha$ ), interleukin 1 beta (II $-1 \beta$ ) and interleukin $6(\mathrm{IL}-6)$, which play important role in the mediation of biological effects of endotoxin ${ }^{10}$. These factors subsequently release other cellular mediators, and activate neutrophils and endothelial cells; these events invariably, lead to adhesion of activated neutrophils to endothelial cells thereby causing vascular injury and $\mathrm{DIC}^{11,12}$ with varying degrees of thrombosis and/or bleeding. In PPF, the degree of thrombosis is usually profound with serious ischaemic injuries to tissues and organs.

This report illustrates the importance of early diagnosis and management of purpura fulminans.

\section{Case illustration}

A 3.5 year-old girl presented to our facility with a 3-day history of fever associated with vomiting and diarrhoea, and a day of difficulty with breathing, restlessness and yellowness of the eyes.

She was not clinically dehydrated but was severely pale,

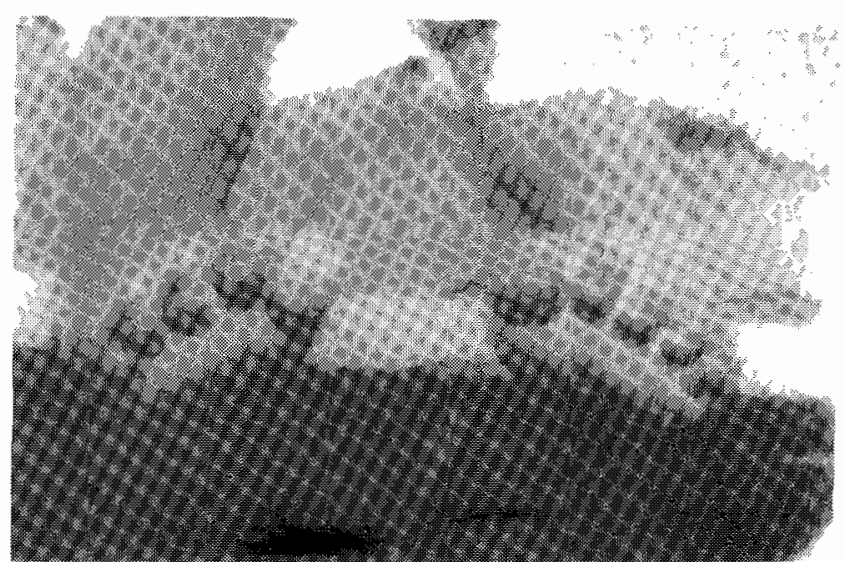

Fig. 1 Swollen feet and gangrenous toes. Amputations of 4th and 5 th toes of the left foot occurred on day 18 of the illness. Autoamputated toes not shown because patient took voluntary discharge before photograph could be taken. 
Table 1 Results of haematological and microbiological investigations

\begin{tabular}{|c|c|c|c|c|c|}
\hline \multirow[b]{2}{*}{ Investigations } & \multicolumn{3}{|c|}{ Days } & \multirow[b]{2}{*}{9} & \multirow[b]{2}{*}{18} \\
\hline & 1 & 3 & 5 & & \\
\hline \multicolumn{6}{|l|}{ Haematology } \\
\hline Haematocrit $(30-42 \%)$ & 17 & 21 & 25 & 24 & 28 \\
\hline WBC count $(3,500-8,500 / \mathrm{cmm})$ & 15,300 & 18,000 & - & 16,700 & 10,800 \\
\hline \multicolumn{6}{|l|}{ WBC differentials } \\
\hline - Lymphocyte, \% & 70 & 66 & - & 63 & 62 \\
\hline - Neutrophil, \% & 28 & 34 & - & 37 & 35 \\
\hline - Eosinophil, \% & 2 & - & - & - & 3 \\
\hline Platelet count $(150,000-400,000 / \mathrm{cmm})$ & 96,000 & 11,000 & - & 42,000 & 85000 \\
\hline Reticulocyte count $(0.2-2 \%)$ & 0.3 & 5 & - & 3 & 1.1 \\
\hline Fragmented red blood cells & Nil & Numerous & - & Numerous & Few \\
\hline Bleeding time (2-5min) & - & 32 & - & - & 3 \\
\hline Whole blood clotting time (4-10 $\mathrm{min})$ & - & 60 & - & - & 7 \\
\hline \multicolumn{6}{|l|}{ Prothrombin time (PT) $12-16 \mathrm{sec})$} \\
\hline - Patient & - & 28 & - & - & 15 \\
\hline - Control & - & 13 & _- & - & 12 \\
\hline$-\mathrm{PT}$ ratio $(1.2-1.3)$ & - & 2.2 & - & - & 1.3 \\
\hline \multicolumn{6}{|l|}{ Microbiology } \\
\hline \multicolumn{6}{|l|}{ Blood } \\
\hline Culture & KR isolated & - & -. & - & - \\
\hline - Malaria parasites & Nil & - & Nil & - & - \\
\hline \multicolumn{6}{|l|}{ Cerebrospinal fluid } \\
\hline - Colour & Turbid & - & - & - & - \\
\hline - Neutrophils & $150 / \mathrm{cmm}$ & - & - & - & - \\
\hline - Gram stain & Gram negative bacilli & - & - & - & - \\
\hline -Culture & Sterile & - & - & - & - \\
\hline Urinalysis & Normal & - & $\begin{array}{l}\text { Epithelial } \\
\text { Cells 1+ }\end{array}$ & - & $\begin{array}{l}\text { Epithelial } \\
\text { cells } 3 \text { - }\end{array}$ \\
\hline Urine Culture & Sterile & - & Sterile & - & Sterile \\
\hline
\end{tabular}

Normal range of values are in brackets

$K R=$ Klebsiella rhinoscleromatis: Sensitive to gentamicin, cefuroxime, tetracycline, co-trimoxazole, ceftriaxone and coli tin. Reagents for partial thromboplastin time were not available as at the time this patient was seen.

mildly icteric. very dyspnoeic, irritable and talking irrationally. She weighed $15 \mathrm{~kg}$ and was $98 \mathrm{~cm}$ tall. Body temperature, respiratory ratc, pulse rate and blood pressure were $39^{\circ} \mathrm{C}, 80$ cycles/ minute, 154 pulsations/minute and $90 / 60 \mathrm{mmHg}$, respectively. The pulse was bounding and irregular; heart rhythm was galloping. There were bilateral chest crepitations: Liver and spleen were enlarged to $8 \mathrm{~cm}$ and $6 \mathrm{~cm}$ below the costal margins, respectively; both were soft, smooth but tender. Bowel sounds were diminished in intensity. Nuchal rigidity and Kernig's sign were demonstrable.

The initial diagnosis was septiceamia complicated by meningitis and anaemic heart failure \pm bronchopneumonia. Intravenous (IV) chloramphenicol, $1.5 \mathrm{~g} /$ day and IV crystalline penicillin, 6 mega units/day were started in four divided doses, respectively. She was transfused with $150 \mathrm{ml}$ of packed cells (haematocrit was 17\%) in addition to IV frusemide; she was later digitalised. Results of relevant investigations requested, are shown in Table 1.

She bled from injection and venepuncture sites, nose and gums on the third day of admission; furthermore, the oropharynx and soft palate were found to be haemorrhagic. Symmetrical purpuric rashes were also observed on the trunk, buttocks and the four limbs thus suggesting the possibility of DIC. She equally bled (ecchymoses) into dorsal and plantar surfaces of distal one-third of both feet and toes. The haemorrhagic areas of both feet were initially purplish but later became purplishblack, cold, swollen and tender. The dorsalis pedis arteries were, however, palpable. Repeat haematocrit was $21 \%$ and the patient was again transfused, with $300 \mathrm{ml}$ of fresh whole blood (FWB) in view of the suspected DIC and on-g oing blood losses. Bleeding, stopped the day after. By the 5th day, the toes had become gangreneous (Figure 1) thus indi ating progression to PPF. This was followed by necrosis of $t$ te dorsum of both feet (distal one-third) on the 8th day. X-rays of both feet were normal.

Oliguric ARF was also observed on day 5, a ad plasma and urinary investigations confirmed renal insufficiency (Table 2). Fluid intake per day was subsequently restricted to insensible fluid losses $\left(300 \mathrm{ml} / \mathrm{M}^{2} /\right.$ day $)$ and urine vol me in the previous 24 hours. Protein intake was reduced to $\mathrm{g} / \mathrm{kg} / \mathrm{day}$ ). The oliguric phase lasted one week. Renal functior gradually improved with the onset of the diuretic phase, and : ppropriate correction of associated fluid and electrolytes deran Igement.

Klebsiella rhinoscleromatis was isolated from the blood on the 6th day of admission and antibiotics were cha aged to IV cefuroxime (500mg 8 hourly) and intramuscular y rentamicin (40ng once daily) based on antibiotic sensitivity eport (Table 1). Low-dose gentamicin was administered ince daily because of the ARF.

The high body temperature gradually returned to normal $\left(36.5^{\circ} \mathrm{C}\right)$ by the 18 th day. The meningitic signs had resolved 6 days earlier. However, auto-amputations of 4 th and th toes of the left foot occurred on day 18 and patient was 'olurtarily discharged from the hospital 3 days later.

\section{Discussion}

This case illustrates the severe and distressful r ourse septicaemia may take in a child, especially when it is cimmplicated 
Table 2 Results of biochemical investigations

\begin{tabular}{|c|c|c|c|c|c|c|c|}
\hline \multirow[b]{2}{*}{ Investigation } & \multicolumn{5}{|c|}{ Days } & \multirow[b]{2}{*}{18} & \multirow[b]{2}{*}{20} \\
\hline & 1 & 5 & 8 & 11 & 14 & & \\
\hline \multicolumn{8}{|l|}{ Plasma } \\
\hline Random Blood glucose $(2.2-10 \mathrm{mmol} / \mathrm{L})$ & 2.7 & 2.5 & - & - & - & 4.7 & - \\
\hline Total bilirubin (up to $20 \mu \mathrm{mol} / \mathrm{L}$ ) & 102 & 208 & - & 217 & 140 & 107 & 95 \\
\hline Conjugated bilirubin (up to $5 \mu \mathrm{mol} / \mathrm{L}$ ) & 70 & 119 & - & 170 & 95 & 76 & 55 \\
\hline Sodium $(136-145 \mathrm{mmol} / \mathrm{L})$ & 133 & 120 & 125 & 130 & 129 & 132 & 136 \\
\hline Potassium $(3-5 \mathrm{mmol} / \mathrm{L})$ & 3.0 & 5.3 & 5.8 & 5.5 & 4.0 & 3.5 & 3.5 \\
\hline Bicarbonate $(26-30 \mathrm{mmol} / \mathrm{L})$ & 24 & 18 & 15 & 19 & 23 & 26 & 25 \\
\hline Phosphate $(0.65-1.3 \mathrm{mmol} / \mathrm{L})$ & 1.03 & 1.8 & 2.08 & 2.0 & 1.43 & 1.0 & 0.7 \\
\hline Calcium $(2.25-2.75 \mathrm{mmol} / \mathrm{L})$ & 2.4 & 1.2 & 1.0 & 1.2 & 1.75 & 2.1 & 2.5 \\
\hline Urea $(2.5-7 \mathrm{mmol} / \mathrm{L})$ & 6.0 & 22.8 & 25.0 & 30.9 & 21.5 & 12.8 & 5.5 \\
\hline Uric acid $(0.12-0.36 \mu \mathrm{mol} / \mathrm{L})$ & 0.15 & 0.5 & 0.5 & 0.76 & 0.25 & - & 0.13 \\
\hline Creatinine $(30-80 \mu \mathrm{mol} / \mathrm{L})$ & 70 & 215 & 583 & 732 & 432 & 225 & 106 \\
\hline Protein $(60-80 \mathrm{~g} / \mathrm{L})$ & 55 & 55 & - & - & - & - & 60 \\
\hline Albumin $(35-55 \mathrm{~g} / \mathrm{L})$ & 38 & 24 & - & - & - & & 31 \\
\hline \multicolumn{8}{|l|}{ Cerebrospinal Fluid } \\
\hline Protein $(15-45 \mathrm{mg} / \mathrm{dl})$ & 85 & - & - & - & - & - & - \\
\hline Glucose $(2.7-3.9 \mathrm{mmol} / \mathrm{L})$ & 1.2 & - & - & - & - & - & - \\
\hline \multicolumn{8}{|l|}{ Urine } \\
\hline Protein & - & $2+$ & - & - & - & $1+$ & - \\
\hline Specific gravity $(1.025-1.035)$ & - & 1.012 & - & - & - & 1.018 & - \\
\hline FeNa $(1 \%)$ & - & 3.5 & - & - & - & 1.8 & 1.35 \\
\hline $\begin{array}{l}\text { Creatinine clearance } \\
\left(86-162 \mathrm{ml} / \mathrm{min} / 1.73 \mathrm{M}^{2}\right)\end{array}$ & - & 18.23 & - & - & - & - & 47 \\
\hline
\end{tabular}

- Figures in brackets = Normal range of values

- FeNa = Fractional excretion of filtered sodium; values greater than $1 \%$ suggest ARF

by a fulminating purpura.

Fever, purpuric rashes, gross haematuria, palor, varying degrees of renal and neurological dysfunction are some of the clinical features of the CTHDs ${ }^{1,6}$. Some of the laboratory features include microangiopathic haemolytic anaemia (presence of fragmented red blood cells on peripheral blood film), thrombocytopaenia, reticulocytosis, microscopic haematuria, proteinuria and elevated blood urea nitrogen ${ }^{1,6}$. It can therefore, be very difficult distinguishing one form of CTHD from the other; and without critical appraisal of some salient features, one can easily be misdiagnosed for the other. This explains why the bleeding diatheses were initially ascribed to DIC in this patient. Uniformly symmetrical purpura or ecchymosis, symmetrical peripheral gangrene, prolonged PT and PTT are present in PPF but are absent in both HUS and TTP ${ }^{1,6}$. Prolonged PT and PTT are common to both PPF and DIC but uniformly symmetrical purpuric/ecchymotic lesions (or necrosis) and peripheral gangrene which are the hallmarks of PPF, are absent in DIC DI, $^{10}$

Clinical and laboratory features in this patient typify a classical case of PPF. PPF occurs mainly in patients with either acquired ${ }^{3.5}$ or congenital ${ }^{13,14}$ deficiencies of the natural anticoagulants (NACs) which prevent undue systemic thrombosis. NACs include proteins $\mathrm{C}$ and $\mathrm{S}$ and antithrombin III (ATIII) ${ }^{15}$. Usually, PPF occurs spontaneously in congenital deficiencies of the NACs ${ }^{13,14}$. On the other hand, it is often provoked by acquired deficiencies of the NACs following severe infections $s^{3,5}$. Our patient possibly had acquired deficiencies of the NACs. In centers where facilities for assaying for proteins $\mathrm{C}$ and $\mathrm{S}$, and $\mathrm{AT}-\mathrm{III}$ are lacking, early diagnosis of PPF before onset of thrombotic skin necrosis and gangrene with or without end-organ failure(s) may be very difficult in patients with purpura or ecchymosis. Failure to diagnose PPF before onset of skin necrosis, digital gangrene and ARF in our patient, demonstrated this difficulty. Ability to assay for plasma levels of the NACs appears to be the surest means of making early diagnosis of PPF.

Of the three NACs, protein $\mathrm{C}$ is often the most deficient in $\mathrm{PPF}^{16}$. A strong correlation has been established between the severity of acquired protein $\mathrm{C}$ deficiency and extent of thrombotic skin lesions and adverse clinical outcome ${ }^{16}$.

Approach to treatment of PPF is often multi-dimentional; it encompasses replacement of deficient NACs especially protein $\mathrm{C}$, heparinization, antibiotic therapy, judicious management of end-organ dysfunctions, skin grafting and surgical amputation of gangrenous limb(s) when indicated $d^{1,3,7,17}$.

Monoclonal antibody purified protein $\mathbf{C}$ concentrate had been administered to patients by continuous IV infusion with good results ${ }^{3,15}$. Where protein $\mathrm{C}$ concentrate is not available, fresh frozen plasma or FWB may be transfused to replace deficient NACs, coagulation factors and platelets. Transfused FWB partly helped in limiting further progression of the thrombotic skin necrosis and gangrene in our patient.

Heparin therapy is not encouraged in DIC because of its potential for aggravating haemorrhage and thrombocytopaenia ${ }^{18}$; it, however, remains an effective therapeutic agent in PPF because of its anti-coagulatory and anti-inflammatory properties $^{19-20}$. Heparin potentiates the anti-coagulatory action of AT-III. And whithout adequate plasma level of AT-III (level $\geq 35 \mathrm{IU} / \mathrm{ml}$ ), heparin therapy will be ineffective. ${ }^{3}$. Some treatment failures, may infact be due to this. Heparin also binds TNF- $\alpha, \mathbb{L}-1 \beta$ and $\Pi L-6$ in addition to inhibiting their synthesis by monocytes, thereby limiting cytokine-mediated vascular injury and thrombosis ${ }^{19,20}$. Higher levels of these proinflammatory cytokines in PPF, have been associated with high mortality rate ${ }^{21}$. Early treatment with heparin, reduces 
the risk of digital necrosis and subsequent amputation ${ }^{17}$. A loading dose of about 50units $/ \mathrm{kg}$ of IV heparin followed by a continuous IV infusion of 10-20 units/kg/hour is considered much physiologically safer than intermittent injections? ${ }^{7}$. The problems of hacmorrhage and thrombocytopaenia associated with regular heparin have been reasonably overcome with the use of low molecular weight heparins. Low molecular weight heparins are given once daily, and are not associated with heparin-induced thrombocytopaenia ${ }^{22,23}$. The bleeding diatheses which were initially ascribed to DIC, precluded heparin therapy in our patient.

Although ARF was successfully managed in our patient without dialysis, some workers have claimed better outcome with continuous venovenous haemodiafiltration (CVVHD) ${ }^{3}$. Low morbidity and mortality rate have been associated with sepsis-related ARF when CVVHD is commenced early in the course of sepsis, to remove proinflammatory cytokines ${ }^{24,25}$.

Fulminating purpura may initially masquerade as DIC! Therefore, presence of uniform and symmetrically distributed purpura and/or ecchymoses in any sick child with sepsis should strongly arouse the suspicion of PPF. Definitive management should be instituted before onset of thrombotic skin necrosis, peripheral gangrene and end-organ failure(s).

\section{References}

1. Marder VJ. Consumptive thrombohaemorrhagic disorders. In Haematology eds. William W. J., Beutler E, Erslev A. J., Lichtman M. A. New York: MoGraw Hill. 1990; pp1522 - 43.

2. Hoffbrand AV, Petiti JE. Purpura associated with infection. In clinical haematology eds. Hoffbrand AV, Petit J. E. London: Times Mirror International Publishers Limited. 1994; pp. 284 - 84.

3. Smith OP, White B, Vaughan D, Rafferty M, Claffey L, Lyons B, Casey W. Use of protein $C$ concentrate, heparin and haemodiafiltration in meningococcus-induced purpura fulminans. Lancet. 1997; 350: $1590-93$.

4. Penington D, Rush B, Castaldi P. Microcirculation thrombosis. In Clinical hamatology in medical practice eds. Penington D. Rush B, Castaldi P. London: Blackwell Scientific Publications. 1978; pp $765-66$.

5. Ohnishi M, Shimizu $Y$, Iwata $K$, Ookochi $Y$, Ooek. Purpura fulminans complicating pneumococcal sepsis: a case report. J. Jpn. Assoc. Infect. Dis. 9: 1117-21.

6. Geoge JN, Aster RH. Thrombocytopaenia due toenhanced platelet destruction by nonimmunologic mechanisms. In Haematology eds. William WJ, Beutler E, Ersleve AJ, Lichtman MA. New York: McGraw Hill. 1990; pp. 1351 - 70.

7. Higartner MW, McMillan $\mathrm{CW}$. Disseminated intravascular coagulation. In Blood diseases of infancy and childhood eds. Miler, D. R., Baehner R. L. McMillan, C. W. Missouri: CVMosby Company. 1984 ; pp. $900-904$.

8. Glauser MP, Zanetti G, Baumgartner JD, Cohen J. Septic Shock: Pathogenesis. Lancet 1991; 338: 732 - 6.

9. Spika JS, Peterson P, Wilkinson J. et al Role of peptidoglycan from Staphylococcus aureus in leukopaenia, thrombocytopaenia, and complement activation with bacteraemia. J. Infect.
Dis. 1982; 146: 227 - 34 .

10. Tracey KJ, Vlassara $H$, Cerami A. Peptide regulator y factors: cachectin/tumour necrosis factor. Lancet. 1: 1122-5.

11. Figari IS, Mori NA, Palladino MA. Jr. Regulation of 1 eutrophil migration and super oxide production by reombinan TNF alpha and beta: comparison to recombinant interferon ga/mma, and interleukin-1 alpha. Blood. 1987; 70: $979-84$.

12. Parrillo JE. Pathogenetic mechanisms of septic shock. IV. Eng. J. Med. 328: $1471-7$.

13. Baliga V, Thwaites R, Tillyer ML, Minford A, Parapia L Allgrove J. Homozygous protein $\mathrm{C}$ deficiency management with protein $\mathrm{C}$ concentrate. Eur. J. Paediatr 1995; 154(7): 534 - 38.

14. Muller FM, Ehrenthal W, Hafner G, SchranzD. Purpura Uulminans in severe congenital protein $D$ deficiency: monitoring; of treatment with protein C concentrate. Eur. J. paediatr. 1991; 155(1): $20-5$.

15. Heyderman RS. Severe sepsis and intravascular thromb sis. Anch Dis. Child. 1993; 68: 621 - 25 .

16. Fijnvandraat $K$, Derkx $B$, Peters $M$. et al: Coagulation tctivation and tissue necrosis in meningococcal septic shock: se verely reduced protein $\mathrm{C}$ levels predict a high mortality. Throm. Haemost. 1995; 73: $15-20$.

17. Kuppermann $\mathrm{N}$, Inkelis $\mathrm{S}$, Saladino $\mathrm{R}$. The role of hep rrin in the prevention of extremity and digit necrosis in meningoc sccal purpura fulminans. Paediatr. Infect. Dis. J. 1994; 13: 867 - 87 .

18. First LR. Disseminated intravascular coagulation. In ?aediatric Medicine eds. Avery, M.E., First L. R., Baltimore: Wi liams and Wilkins. 1989; pp. $542-43$.

19. Daubener W, Nockemarm S, Gutsche M, Hadding C. Heparin inhibits the antiparasitic and immune modulatory eff cts of human recombinant interferon- $\alpha$. E. J. Immunol. 1995; 25: 688 92.

20. Attanasio M, Gori AM, Givsti E. et al: Cytokine gene r xpression in human stimulated monocytes is inhibited by heparir. Thromb. Haemost. 1997; 77 (Suppl): 9.

21. Waage A, Halstensen A, Espevic T. Association betwe m TNF in serum and fatal outcome in meningococcal disease. Lat icet 1987; i: $355-57$.

22. Green D, Hirsh J, Heit J, Prins M, Davidson B Iensing AWA. Low molecular weight heparin: a critical a ralysis of clinical trials. Pharmacol, Rev. 1994; 46: $89-1$ j9.

23. Hirsh J. Overview of low molecular weight hep trins and heparinoids: basic and clinical aspects. Aust. NZ. J. ME 1. 22: 487 -95 .

24. Bellomo R, Tipping P, Boyce N. Continuous ve 1ovenous haemofiltration with dialysis removes cytokines from $t$ le circulation of patients with sepsis. Crit Care Med. 1993; 21: 522 -26 .

25. Best $C$, Walsh $J$, Sinclair $J$, Beattie . Early haemodiafiltration in meningococcal septicaemi $\_$. Lancet. 1995; 347: 202. 